Research Paper

\title{
A Mechanism for the Temporal Potentiation of Genipin to the Cytotoxicity of Cisplatin in Colon Cancer Cells
}

\author{
Ruihua Wang1, KC MoYung², YJ Zhao², Karen Poon ${ }^{2 \bowtie}$ \\ 1. Department of Gastroenterology, Shenzhen Hospital of Southern Medical University, Shenzhen, Guangdong, China 518100 \\ 2. Program of Food Science and Technology, Division of Science and Technology, BNU-HKBU United International College, 28 Jinfeng Road, Tangjiawan, \\ Zhuhai, Guangdong, China 519085 \\ $\square$ Corresponding author: Karen Poon, PhD. Associate Professor, Program of Food Science and Technology, Division of Science and Technology, BNU-HKBU \\ United International College, 28 Jinfeng Road, Tangjiawan, Zhuhai, Guangdong, P.R. China 519085 karenpoon@uic.edu.hk. Tel: (86) 756-3620621 Fax: (86) \\ $756-3620882$
}

(1) Ivyspring International Publisher. Reproduction is permitted for personal, noncommercial use, provided that the article is in whole, unmodified, and properly cited. See http://ivyspring.com/terms for terms and conditions.

Received: 2016.03.04; Accepted: 2016.05.31; Published: 2016.06.29

\begin{abstract}
OBJECTIVES: To investigate the potentiation effect of Genipin to Cisplatin induced cell senescence in HCT-116 colon cancer cells in vitro. METHODS: Cell viability was estimated by Propidium iodide and Hoechst 3342, reactive oxygen species (ROS) with DHE, mitochondrial membrane potential (MMP) with JC-1 MMP assay Kit and electron current production with microbial fuel cells (MFC). RESULTS: Genipin inhibited the UCP2 mediated anti-oxidative proton leak significantly promoted the Cisplatin induced ROS and subsequent cell death, which was similar to that of UCP2-siRNA. Cells treated with Cisplatin alone or combined with Genipin, ROS negatively, while MMP positively correlated with cell viability. Cisplatin induced ROS was significantly decreased by detouring electrons to MFC, or increased by Genipin combined treatment. Compensatory effects of UCP2 up-regulation with time against Genipin treatment were suggested. Shorter the Genipin treatment before Cisplatin better promoted the Cisplatin induced ROS and subsequent cell death. CONCLUSION: The interaction of leaked electron with Cisplatin was important during ROS generation. Inhibition of UCP2-mediated proton leak with Genipin potentiated the cytotoxicity of Cisplatin. Owing to the compensatory effects against Genipin, shorter Genipin treatment before Cisplatin was recommended in order to achieve better potentiation effect.
\end{abstract}

Key words: Genipin, Cisplatin, cytotoxicity, cell electric current, reactive oxygen species, mitochondrial membrane potential

\section{Introduction}

Cancer is one of the major diseases to cause significant human death per year; therefore, a lot of research efforts have been spent to improve the healing rates. Current therapeutic strategy of cancer treatment is mostly relied on the induction of apoptosis in cancer cells using chemotherapeutic agents. Apoptosis is a cellular process involving series of genetically programmed events leading to cell death, which included the release of caspase activators such as cytochrome c, the change of electron transport, and the loss of mitochondrial membrane potential $(\Delta \Psi \mathrm{m})(\mathrm{MMP}){ }^{[1]}$. One of the critical processes involved is the increase in the formation of mitochondrial permeability transition pore allowing the transport of cytochrome $c$ out of the cytosol [2]. Subsequently, a series of caspase reactions are triggered causing apoptosis ${ }^{[3]}$.

Cisplatin is one of the important chemotherapeutic drugs having high level and broad spectrum of antitumor activity commonly used to treat various human cancers [4]. However, the efficacy of Cisplatin is limited by its toxic side effects and tumor resistance leading to secondary malignancies [5]. Exposure to Cisplatin increased the intracellular reactive oxygen species (ROS) generation in various cancer cells ${ }^{[6-9]}$ dose-dependently ${ }^{[10]}$, and changed the 
MMP [8] leading to the cisplatin-induced cell senescence [9]. Using ROS scavenger N-acetyl-Lcysteine decreasing the ROS level [11] would alleviate the subsequent cell senescence [9,12-13], while the pretreatment of substance increasing the ROS level would potentiate the chemotherapeutic effect of Cisplatin [14]. The induced ROS by Cisplatin was mitochondrial dependent and caused DNA damage. Although the production of ROS did not correlate with the amount of Cisplatin-induced DNA damage [15], ROS was shown to trigger cell death via the ROS mediated induced apoptotic pathways that included the down-regulation of anti-apoptotic protein Bcl-2 [12], activation of caspase 3 and 9 [6], phosphorylation of JNK and p38 [16], and suppression of MRP1 expression [14].

Cancer cells was found to re-engineer their cellular metabolism in order to improve their survival at adverse condition e.g. hypoxia [17]. It was called Warburg effect [17], in which the rate of glycolysis and the formation of lactate in cancer cells increased [17] in order to promote the ATP production and the recycle of $\mathrm{NAD}^{+}$from NADH [17] respectively. Drastic decrease in $\mathrm{pH}$ of the microenvironment surrounding the cancer cells was developed inhibiting the growth of neighboring normal cells [17]. Resistant cancer cells were reported to have the uncoupling protein complex II (UCP2) up-regulated [18], in which the UCP2 promoted the antioxidative proton leak leading to the reduction of ROS [19] in various cancer cells, including leukemia, ovarian, bladder, esophagus, testicular, colorectal, kidney, pancreatic, lung and prostate tumors.

Genipin is an iridoid glycoside component extracted from Gardenia jasminoides Ellis fruit, and also herbal medicine used long time ago to treat hepatic disorders [20]. Genipin has shown diverse pharmacological activities, such as anti-inflammatory[21-22], anti-oxidative [23-25], anti-tumor [20, 26], anti-diabetic [27-29], anti-angiogenic activities [30] and antidepressive activities [16].

Recently, Genipin was demonstrated to be the specific UCP2 inhibitor [18], and was able to sensitize drug-resistant leukemia cells to anthracyclin [15]. The use of Genipin to block the UCP2-mediated proton leak was found to enhance the therapeutic treatment of diabetes [31], and also inhibit the growth of pancreatic adenocarcinoma [32]. However, differential effects of Genipin were reported in studies, including the down-regulation of UCP2 expression in breast cells [18], and the up-regulation in HepG2 cell lines of hepatocytic steatosis [25]. Genipin improved the insulin sensitivity in pancreatic islet cells by regulating the mitochondrial function [27], inhibited ROS overproduction, and alleviated MMP and ATP reduction [27]. On the other hand, Genipin increased ROS and ROS-induced NAPDH-oxidase (NOX) production, triggering apoptosis in gastric cancer cells [33] and in human non-small-cell lung cancer H1299 cells [34]. Genipin's action on ROS production and regulation of UCP2 expression seemed to be determined by the type of experiments and cells.

As Genipin was demonstrated to be the specific $\mathrm{UCP} 2$ inhibitor ${ }^{[18]}$, reduction of UCP2 overexpression in cancer cells is anticipated likely to improve the chemotherapeutic treatment. In this study, we would investigate the potentiation effect of Genipin to Cisplatin in HCT-116 colon cancer cells and its co-treatment methods. Experimental studies would investigate the temporal effect of Genipin and Cisplatin to ROS production, MMP and current production, and their relationships with the potentiation of Genipin to the chemotherapeutic effect of Cisplatin. Using the technique of microbial fuel cell (MFC), electric current could be measured from mammalian cells [35], in which cancer cells were found to produce much higher currents ${ }^{[36]}$. Proton leaking [35] and the expression of UCP2 [36] in cells was found to influence the magnitude of electric current production from cells. The electron and proton leaking from electron transport chain (ETC) was associated with the generation of electric current in MFC [35-36]. Therefore, the use of MFC technique to study the chemotherapeutic effect of drug would provide additional information on the physiological changes in cells.

\section{Materials and Method}

\section{Materials \& Reagents}

All the chemicals used in the experiments were at analytical grade. Hepes was purchased from Yuanye Bio-Technology Co., Ltd, Shanghai; Collagenase IV from Biotech Grade; Percoll from BIOSHARP, Pharmacia; Protonophore 2.4-dinitrophenol (DNP) from Dong Fang Hua Gong (China); ATP synthase inhibitor Resveratrol (RVT) from Sigma, USA. Genipin obtained from ShangHai Yuanye Biological Technology (Shanghai, China) was white crystalline solid stored in the dark at $-20^{\circ} \mathrm{C}$. 2 $\mathrm{mg}$ of Genipin was dissolved into $10 \mathrm{ml}$ DMEM as stock solution and the stock solution was diluted with DEME to $20 \mu \mathrm{M}$ and $40 \mu \mathrm{M}$ with $10 \%$ (v/v) fetal bovine serum and $1 \%(\mathrm{v} / \mathrm{v})$ penicillin. Cisplatin obtained from HanXiang Biological Technology (Shanghai, China) was yellow powder stored in the dark at $-20^{\circ} \mathrm{C} .3 \mathrm{mg}$ of Cisplatin was dissolved into 10 $\mathrm{ml}$ DMEM as stock solution. The stock solution was diluted with DMEM to 25,50 or $100 \mu \mathrm{M}$ with $10 \%$ $(\mathrm{v} / \mathrm{v})$ fetal bovine serum and $1 \%(\mathrm{v} / \mathrm{v})$ penicillin. All 
the prepared chemicals were stored in the dark at $-20^{\circ} \mathrm{C}$.

\section{Culture of cancer cells}

The colon cancer cells HCT-116 were cultured as in the previous studies [36].

\section{Measure electric current produced from different cells with MFC}

Similar to our previous studies [36], colon cancer cells $\left(1 \times 10^{6}\right.$ cells $\left./ \mathrm{ml}\right)$ would be put in the anode of MFC for the current measurement.

The initial 10 minute measurement was used as the baseline value. The change in current production was calculated by subtracting the 10 minute current value measured after the addition of chemical with the 10 minute baseline value. The values from minute 6 to 10 were averaged to obtain the average electric current change.

\section{JC-1 Mitochondrial Membrane Potential Assay}

JC-1 Mitochondrial Membrane Potential Assay Kit was used as in the previous studies [36]. Cell density of $5 \times 10^{5}$ cells $/ \mathrm{ml}$. was used. $0.1 \%$ DMSO was used as control for RVT and DNP, while PBS was used as control for Genipin and Cisplatin.

\section{Reactive Oxygen Species (ROS) Assay}

Using DHE with cell density of $5 \times 10^{5}$ cells $/ \mathrm{ml}$ for ROS assay [36].

\section{Cell viability}

The method using Propidium Iodide (PI) and Hoechst 3342 (HO342) with cell density of $6 \times 10^{4}$ / well was used [36]. Cells were pretreated with 20 or $40 \mu \mathrm{M}$ Genipin, UCP2-siRNA or random-siRNA, for 24 hour, followed by the treatment of 25,50 , or 100 $\mu \mathrm{M}$ cisplatin for another 24 hour.

\section{Cell transfection}

HCT- 116 cells of density at $4 \times 10^{4}$ / well in 48 -well plate without penicillin were were transfected with combination of Lipofectamine 2000 Transfection Reagent and siRNA. Diluted $3 \mu \mathrm{l}$ lipofectamine 2000 Transfection Reagent (Life Technologies Corporation, Guangzhou, China) and 80 pmol UCP2-siRNA or random-siRNA in $1 \mathrm{ml}$ DEME (without penicillin and serum) and incubated at room temperature for 20 min. The cells were rinsed with PBS twice. The mixture of 2000 Transfection Reagent and siRNA was added and incubated for 5-6 hours. After 24 hour, the cells were treated with 25,50 , or $100 \mu \mathrm{M}$ Cisplatin.

UCP2-siRNA (5\#-GAACGGGACACCUUUAGA Gtt-3\#) and random-siRNA (5\#-UUCUCCGAACGU GUCACGUtt-3\#) were dry powder (1 OD per tube), designed by Shanjing Biological Technology
(Shanghai, China). One OD siRNA in a tube was dissolved in $125 \mathrm{ml}$ DEPC- $\mathrm{H}_{2} \mathrm{O}$ to form $20 \mathrm{pmol} / \mu \mathrm{l}$ stock solution stored at $-20^{\circ} \mathrm{C}$ before use.

\section{Biostatistics}

T.Test function in EXCEL was used to return the probability of Student t.test in the calculation of significances between treatment groups.
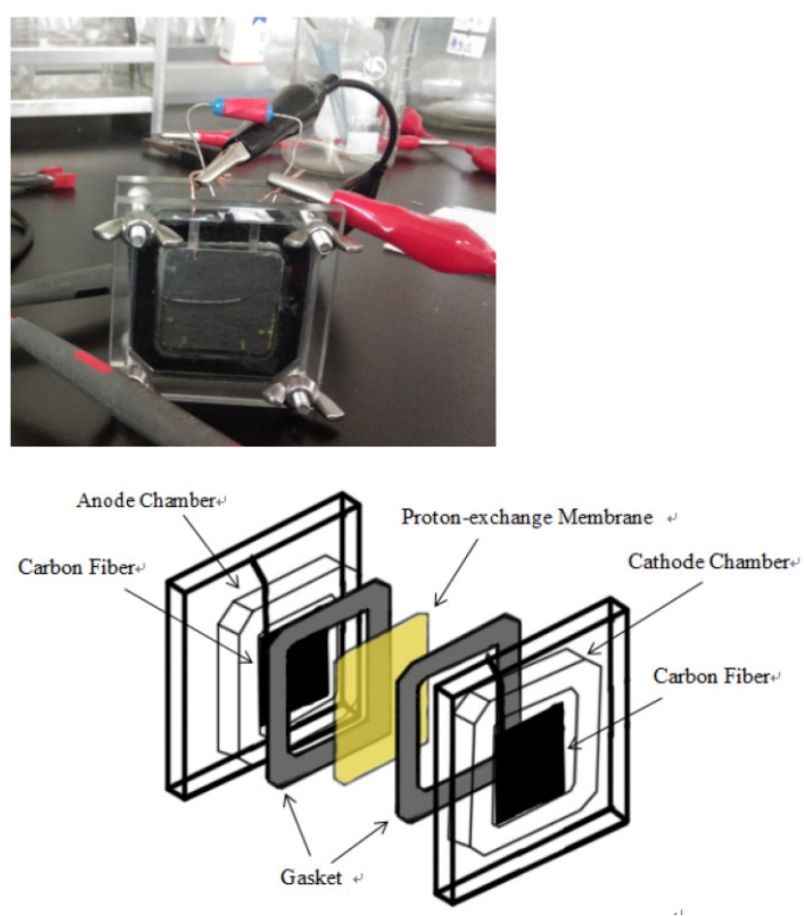

Figure 1. Two chambered MFC with effective volume of $5 \mathrm{ml}$ and flat square shaped electrodes made with carbon paper (Toray, Japan) of surface area at 7.8 $\mathrm{cm}^{2}(2.8 \times 2.8 \mathrm{~cm})$.

\section{Results}

Cisplatin reduced the cell viability of HCT-116 colon cancer cells dose-dependently (Figure 2a) ${ }^{[10]}$. Genipin did not decrease the cell viability (Figure 2a), but potentiated the Cisplatin induced cell death in HCT-116 colon cancer cells (Figure 2a). Higher the Genipin concentration used in the co-treatment, better the potentiation effect was observed (Figure 2a). Co-treatment of Cisplatin with UCP2-siRNA was better than the random siRNA in reducing the cell viability (Figure 2a).

In the present study, Genipin was added before the Cisplatin in treating the colon cancer cells. Data showed that using $40 \mu \mathrm{M}$ Genipin to pretreat the cancer cells for 24 hours, the sequential addition of 25 $\mu \mathrm{M}$ Cisplatin could reduce the cell viability at $67.76 \pm 11.01 \%$ (mean \pm SE). When Genipin and Cisplatin were used to treat the cancer cells at the same time, i.e. to decrease the pretreatment time of Genipin from 24 hours to 0 hour, the therapeutic 
effectiveness of Cisplatin was significantly promoted (Figure $2 \mathrm{a}$ ) with the cell viability at $32.18 \pm 10.45 \%$ that was significantly more effective than that of the 24 hours co-treatment protocol $(* * \mathrm{P}=0.010)$.

Cisplatin elevated the intracellular ROS level [11] of HCT-116 colon cancer cells dose-dependently [10] (Figure 2b). Pretreatment of Genipin for 24 hours did not largely increase the ROS, but promoted the Cisplatin-induced ROS production. Higher the Genipin concentration used in the co-treatment, higher level of ROS promotion was observed accompanying with the increase in cell death (Figure $2 a, b)$. Similarly, pretreatment with UCP2-siRNA promoted the Cisplatin induced ROS and cell death (Figure 2a,b).
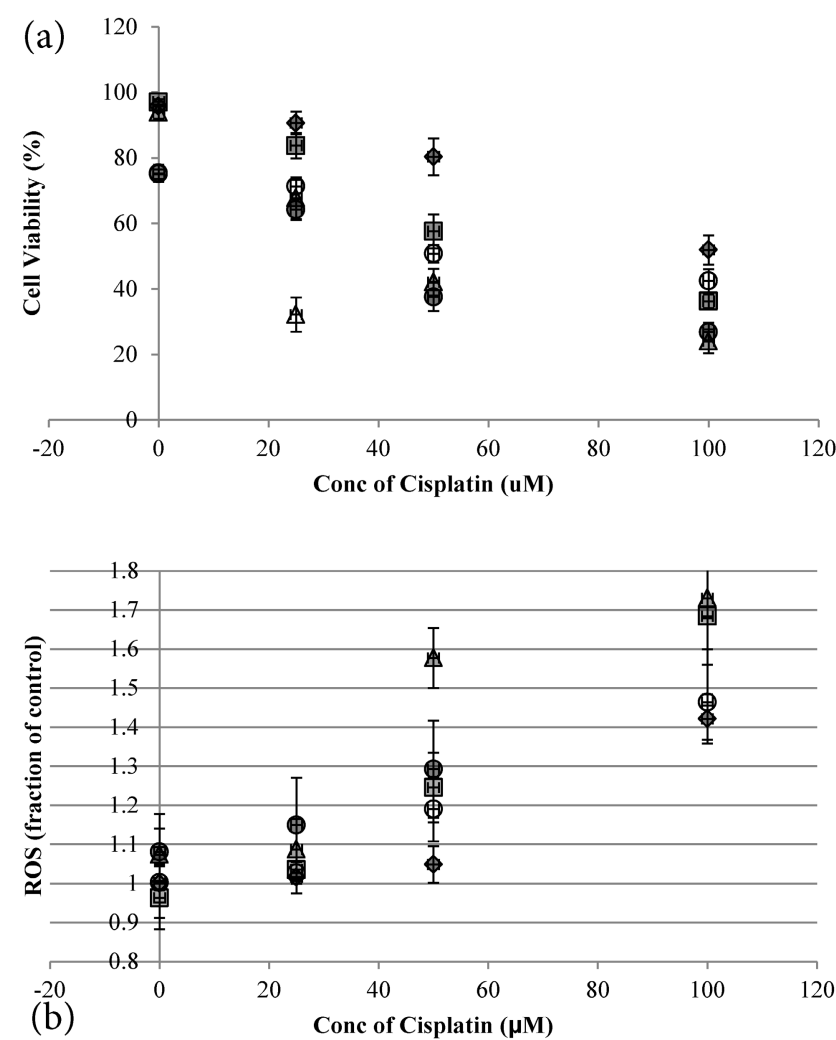

Figure 2. a Cell viability (in percentage of control)(mean $\pm S E$ ) of HCT-116 colon cancer cells 24 hour pretreated with 1) control; 2) - 20 $\mu$ M Genipin; 3) $\triangle 40 \mu M$ Genipin; 4) $\bullet$ UCP2 SiRNA; 5) ○ Random siRNA; before treated with different concentration of cisplatin for another 24 hour. 6) $\triangle$ Same time cotreatment with $25 \mu \mathrm{M}$ Cisplatin and $40 \mu \mathrm{M}$ Genipin for 24 hours. b ROS (in fraction of control)(mean \pm SE) of HCT-116 colon cancer cells 24 hour

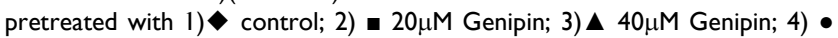
UCP2 SiRNA; 5) ○ Random siRNA; before treated with different concentration of cisplatin for another 24 hour.

ROS levels in the treatment groups with Cisplatin alone or co-treatment with Genipin negatively correlated with the cell viability (Figure 3a). Similar pattern of negative correlation was also observed in the co-treatment with UCP2-siRNA (Figure 3b).
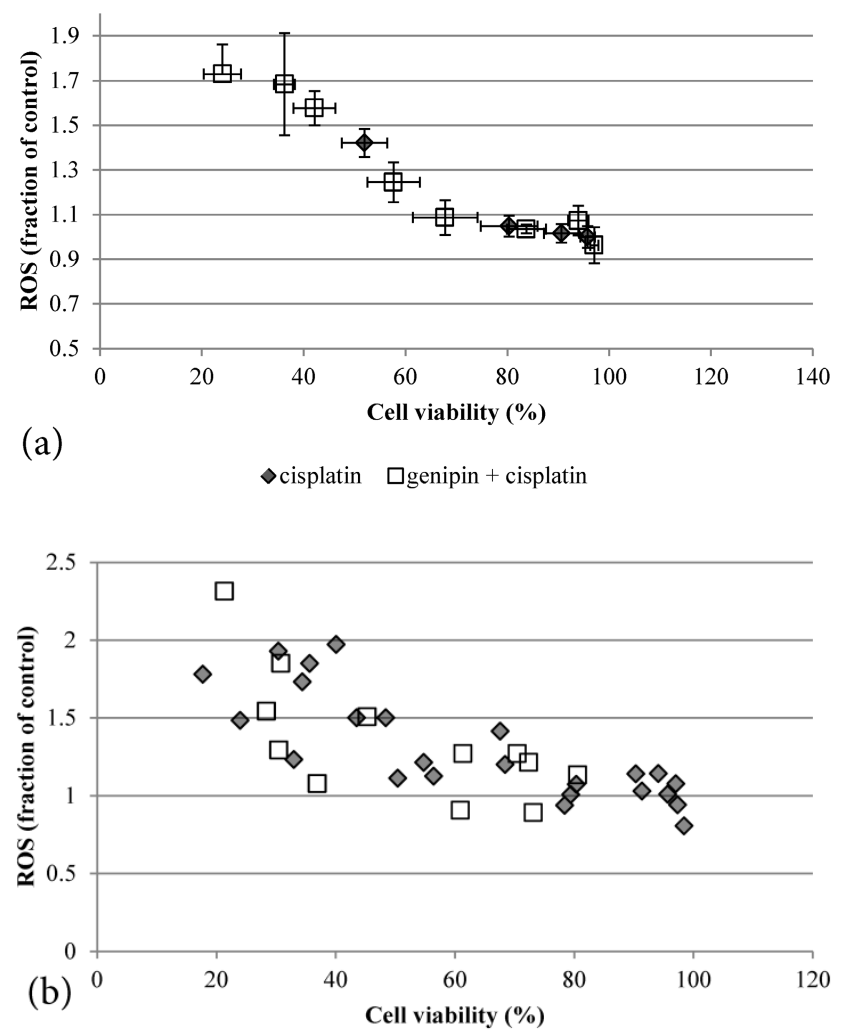

Figure 3. a Plot of ROS (fraction of control) (mean \pm SE) against cell viability (\%) (mean \pm SE) of HCT-116 colon cancer cells treated with 1) $\bullet$ Cisplatin; 2) $\square$ Genipin + Cisplatin。. b Plot of ROS (fraction of control) against cell viability (\%) of HCT-1 16 colon cancer cells treated with 1) $\$ 40 \mu \mathrm{M}$ Genipin $+100 \mu \mathrm{M}$

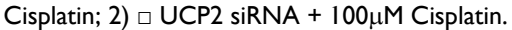

Although both Genipin and Cisplatin increased ROS almost dose-dependently (Figure $4 a, 4 b$ ), the time taken to accumulate significant amount of ROS seemed to be different between Genipin and Cisplatin. Cisplatin took 24 hours to generate significant amount of ROS (Figure 4a) [8], while Genipin generated maximal level of ROS at $10 \mathrm{~min}$ and remained the same at 24 hours (Figure $4 b$ ).

24 hour Cisplatin treatment decreased MMP, in particular at high concentration of $100 \mu \mathrm{M}$ Cisplatin (Figure 5a), which accompanied with high cell death (Figure 2a) ${ }^{[37]}$. The MMP of treated cancer cells at the same cell viability was found to be higher in the co-treatment group of Genipin and Cisplatin than that treated with Cisplatin alone (Figure $5 b$ ).

10 min Genipin treatment increased MMP dose-dependently (Figure 6a), but decreased it in 24 hours (Figure 6a). $10 \mathrm{~min}$ treatment of Cisplatin did not largely alter the MMP value, but decreased it in 24 hours (Figure 6b). HCT-116 colon cancer cells treated with Cisplatin or Cisplatin with Genipin have the ROS level promoted at 24 hours (Figure 7a), while with the MMP level reduced after 24 hours (Figure $7 b)$. 


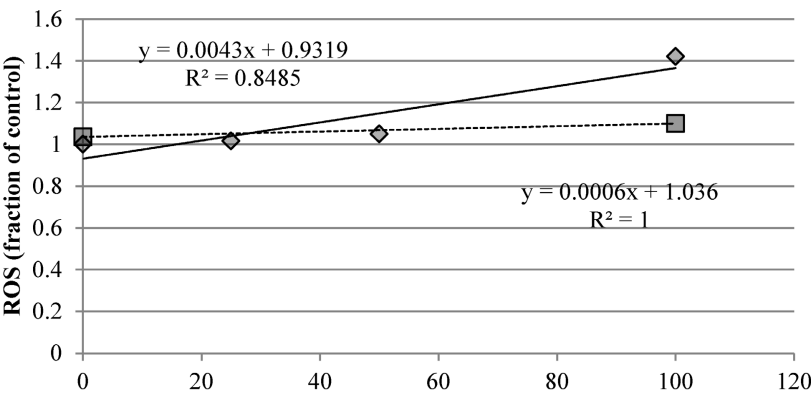

(a)

Cisplatin $\mu \mathrm{M}$

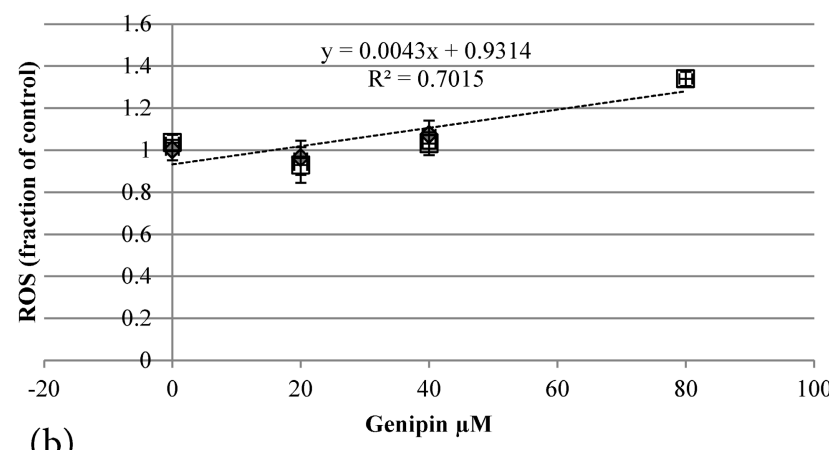

$\diamond \quad 24 \mathrm{hr} \quad \square \quad 10 \mathrm{~min} \quad--------$ Linear $(10 \mathrm{~min})$

Figure 4. a Plot of ROS (fraction of control) of HCT-1 16 colon cancer cells after 1) $-10 \mathrm{~min}, 2$ ) $24 \mathrm{hr}$ Cisplatin treatment versus the concentration of Cisplatin used. b Plot of ROS (fraction of control) of HCT-116 colon cancer cells after 1) $\square 10 \mathrm{~min}, 2)$
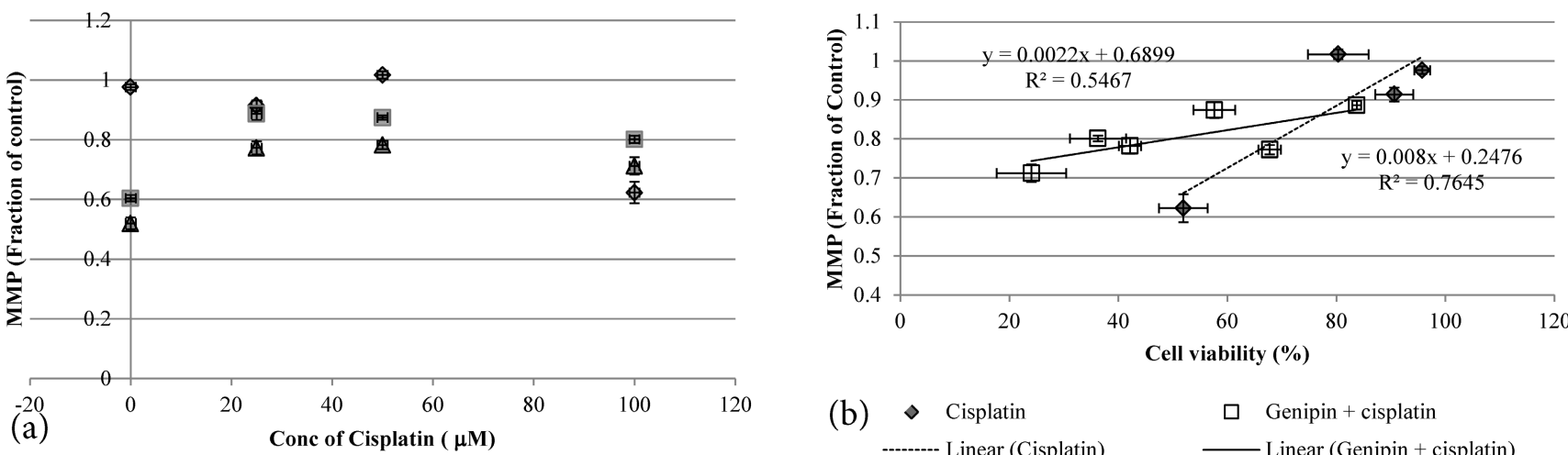

(a) Conc of Cisplatin ( $\mu \mathrm{M})$

(b) $\square$ Genipin + cisplatin

L Linear (Genipin + cisplatin)

Figure 5. a MMP (in fraction of control)(mean \pm SE) of HCT-116 colon cancer cells pretreated 24 hours with 1) control; 2) $120 \mu M$ Genipin; 3) $\Delta 40 \mu M$ Genipin; before being treated with different concentration of cisplatin for another 24 hour. b Plot of MMP (Fraction of control) (mean \pm SE) against cell viability (\%) (mean \pm SE) of HCT-116 colon cancer cells treated with 1) $\diamond$ Cisplatin; 2) $\square$ Genipin + Cisplatin 。

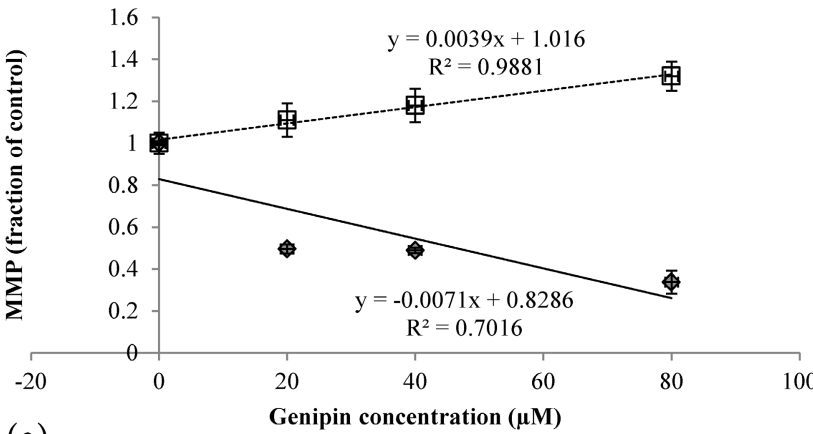

(a)
Genipin concentration $(\mu \mathrm{M})$

$\diamond 24 \mathrm{hr} \square 10 \mathrm{~min} \longrightarrow$ Linear $(24 \mathrm{hr}) \quad$------ Linear $(10 \mathrm{~min})$

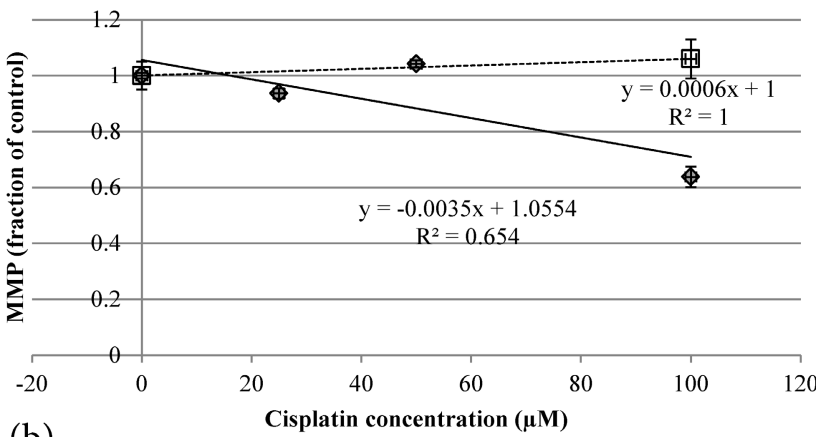

(b)

Figure 6. a Plot of MMP (Fraction of control) (mean \pm SE) of Genipin treated HCT-116 colon cancer cells at 1) $\square 10$ min, 2) 24 hours versus against Genipin concentration $(\mu \mathrm{M})$ used. b Plot of MMP (Fraction of control) (mean \pm SE) of Cisplatin treated HCT-116 colon cancer cells at 1 ) $\square 10$ min, 2) 24 hours versus against Cisplatin concentration $(\mu \mathrm{M})$ used. 

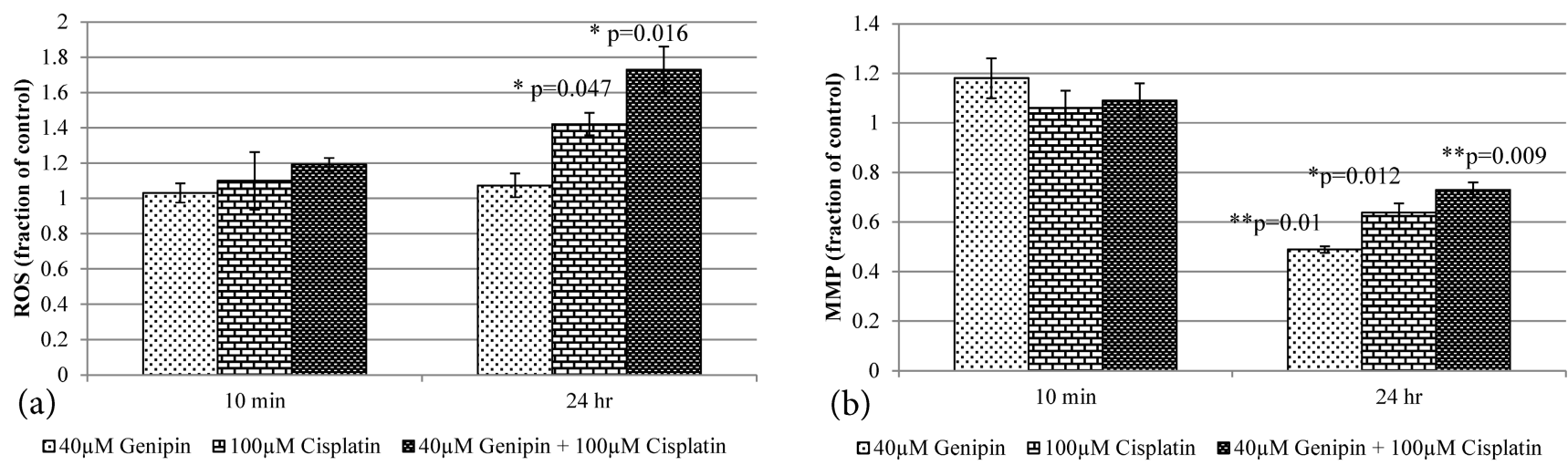

Figure 7. a Plot of ROS (Fraction of control) (mean \pm SE) of 1) $40 \mu \mathrm{M}$ Genipin, 2) 100 $\mu$ M Cisplatin, 3) $40 \mu M$ Genipin and $100 \mu M$ Cisplatin, treated HCT-116 colon cancer cells for $10 \mathrm{~min}$ and 24 hours. Student T.test against 10 min corresponding group $* \mathrm{p} \leq 0.05$. b Figure 6a Plot of MMP (Fraction of control) (mean \pm SE) of 1 )

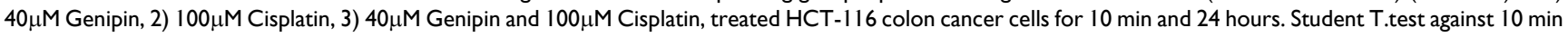
corresponding group * $\mathrm{p} \leq 0.05 ; * * \mathrm{p} \leq 0.01$.

Table 1. Average electric current change in HCT-116 cancer cells with various treatments.

\begin{tabular}{|c|c|c|}
\hline $\begin{array}{l}\text { Average electric current change in } \\
\text { HCT-116 cancer cells after the } \\
\text { treatment of }\end{array}$ & $\mu \mathrm{A}(\operatorname{mean} \pm \mathrm{SE})$ & $\begin{array}{l}\text { Student T. test } \\
\text { against control } \\
\text { PBS or DMSO }\end{array}$ \\
\hline 10 min treatment of Control PBS, then & $-4.84 \pm 4.01$ & \\
\hline add $40 \mu \mathrm{M}$ Genipin & $-131.80 \pm 7.04$ & **P=0.000 \\
\hline $\begin{array}{l}10 \text { min treatment of Control } 0.1 \% \\
\text { DMSO, then }\end{array}$ & $-1.70 \pm 9.21$ & \\
\hline add 20ppm DNP & $76.33 \pm 10.63$ & $* * \mathrm{P}=0.005$ \\
\hline add 20ppm RVT & $28.54 \pm 2.50$ & ${ }^{*} \mathrm{P}=0.033$ \\
\hline $\begin{array}{l}10 \mathrm{~min} \text { treatment of } 40 \mu \mathrm{M} \text { Genipin, } \\
\text { then }\end{array}$ & $-131.80 \pm 7.04$ & $* *=0.000$ \\
\hline add 20ppm DNP & $91.62 \pm 8.54$ & $\approx * P=0.000$ \\
\hline add 20ppm RVT & $-91.89 \pm 10.29$ & * $\mathrm{P}=0.018$ \\
\hline $\begin{array}{l}10 \text { min treatment of } 25 \mu \mathrm{M} \text { Cisplatin, } \\
\text { then }\end{array}$ & $22.33 \pm 4.86$ & ${ }^{*} \mathrm{P}=0.035$ \\
\hline add $20 \mathrm{ppm}$ DNP & $25.01 \pm 2.20$ & \\
\hline add 20ppm RVT & $23.52 \pm 4.88$ & \\
\hline $\begin{array}{l}10 \text { min treatment of } 25 \mu \mathrm{M} \\
\text { Cisplatin }+40 \mu \mathrm{M} \text { Genipin, then }\end{array}$ & $15.83 \pm 2.30$ & *P $=0.038$ \\
\hline add 20ppm DNP & $11.64 \pm 0.95$ & \\
\hline add 20ppm RVT & $18.58 \pm 2.47$ & \\
\hline $\begin{array}{l}24 \text { hour treatment of } 25 \mu \mathrm{M} \\
\text { Cisplatin }+40 \mu \mathrm{M} \text { Genipin, then }\end{array}$ & & \\
\hline add Control $0.1 \%$ DMSO & $10.16 \pm 1.43$ & \\
\hline add 20ppm DNP & $16.97 \pm 1.65$ & * $P=0.034$ \\
\hline add 20ppm RVT & $9.90 \pm 1.67$ & \\
\hline
\end{tabular}

Student $\mathrm{T}$. test against control PBS or DMSO, ${ }^{\mathrm{P}} \leq 0.05,{ }^{* *} \mathrm{P} \leq 0.01$; against

corresponding group $* P \leq 0.05, * P \leq 0.01$

Treatment of $40 \mu \mathrm{M}$ Genipin in HCT-116 colon cancer cells significantly decreased the average electric current change (Table 1), while 20 ppm DNP or 20 ppm RVT significantly increased it (Table 1). Treating the cancer cells 10 min with $25 \mu \mathrm{M}$ Cisplatin was found to significantly increase the electric current production, and abolished the subsequent cell response to DNP in increasing the electric current production (Table 1), while such a low dose could not induce significant cell death (Figure 2a) or ROS generation (Figure 2b). 10 min pretreatment with 40 $\mu \mathrm{M}$ Genipin in HCT-116 colon cancer cells would not abolish the electric current promoting effect of $20 \mathrm{ppm}$ DNP (Table 1).

Cisplatin induced ROS generation in plate condition was significantly reduced in MFC condition (Table 2). 10 min Genipin and Cisplatin co-treatment in plate condition produced higher level of ROS than that of the corresponding group treated with Cisplatin alone (Table 2).

Table 2. ROS and MMP of HCT-116 Colon cancer cells after 10 treatment in plate or in MFC

\begin{tabular}{|l|l|l|l|l|}
\hline $\begin{array}{l}\text { HCT-116 colon } \\
\text { cancer cells after } \\
10 \text { min treatment } \\
\text { in plate or in } \\
\text { MFC }\end{array}$ & $\begin{array}{l}\text { ROS in plate } \\
\text { (fraction of } \\
\text { control) }\end{array}$ & $\begin{array}{l}\text { ROS in } \\
\text { MFC } \\
\text { (fraction of } \\
\text { control) }\end{array}$ & $\begin{array}{l}\text { MMP in } \\
\text { plate } \\
\text { (fraction of } \\
\text { control) }\end{array}$ & $\begin{array}{l}\text { MMP in MFC } \\
\text { (fraction of } \\
\text { control) }\end{array}$ \\
\hline Control & $1.00 \pm 0.03$ & $1.01 \pm 0.03$ & $1.00 \pm 0.05$ & $0.99 \pm 0.03$ \\
\hline $20 \mu \mathrm{M}$ Genipin & $0.90 \pm 0.08$ & $1.06 \pm 0.05$ & $1.11 \pm 0.08$ & $1.03 \pm 0.01$ \\
\hline $40 \mu \mathrm{M}$ Genipin & $0.99 \pm 0.05$ & $1.08 \pm 0.02^{*}$ & $1.18 \pm 0.08$ & $1.11 \pm 0.07$ \\
\hline $80 \mu \mathrm{M}$ Genipin & $1.28 \pm 0.04^{* *}$ & $1.29 \pm 0.04^{*}$ & $1.32 \pm 0.07^{* *}$ & $1.35 \pm 0.09^{* *}$ \\
\hline $100 \mu \mathrm{M}$ Cisplatin & $1.06 \pm 0.09$ & $0.98 \pm 0.08$ & $1.06 \pm 0.07$ & $1.08 \pm 0.01^{*}$ \\
\hline $\begin{array}{l}40 \mu \mathrm{M} \text { Genipin }+ \\
100 \mu \mathrm{M} \text { Cisplatin }\end{array}$ & $1.15 \pm 0.04^{*}$ & $0.95 \pm 0.06^{\xi}$ & $1.09 \pm 0.07$ & $1.10 \pm 0.02^{*}$ \\
\hline
\end{tabular}

Student $\mathrm{T}$. test against corresponding control group, ${ }^{*} \mathrm{P} \leq 0.05,{ }^{* *} \mathrm{P} \leq 0.01$

\section{Discussion}

\section{Genipin potentiated Cisplatin's induced cell death via ROS production}

Cisplatin is an important drug used to treat various types of cancers and reduced the cell viability of HCT-116 colon cancer cells dose-dependently (Figure 2a) ${ }^{[10]}$. However Cisplatin-induced toxic side 
effect and the resistance developed in cancer cells limited its applications [5]. Previous studies indicated that co-treatment of Cisplatin with some other chemicals, e.g. L-buthionine sulfoximine [38], oxamate and galloflavin [39], would promote the cytotoxicity and decrease the amount of Cisplatin used in the treatment alleviating the toxic side effect without scarifying the therapeutic efficacy.

The mechanisms of drug resistance are complex and not fully clear ${ }^{[40]}$. Resistant cancer cells were found to upregulate the UCP2 protein in ETC[18]. Therefore, using Genipin to suppress the UCP2-mediated[18,36] anti-oxidative effect[10,41,42] were anticipated to potentiate the Cisplatin's cytotoxicity to cancer cells. Similar potentiation effect observed in UCP2-siRNA co-treatment further supported the notion of UCP2 inhibition in potentiating the cytotoxicity of Cisplatin in HCT-116 colon cancer cells.

Although complete prevention of ROS generation e.g. by inhibiting complex I in ETC and inhibiting GSH reductase could not prevent the Cisplatin-induced cell death [43], it led to the question if ROS generation was the direct cause of Cisplatin-induced cell death. No matter it is a direct cause or not, links between ROS generation and cisplatin-induced accelerated senescence were observed and confirmed [9], in which Cisplatin elevated ROS generation inducing subsequent cell senescence via various pathways, e.g. phosphorylation of JNK and p38[16], ROS-mediated suppression of MRP1 expression[14], activated caspase 3 and $9[6]$, eventually leading to the apoptosis of cells. The negative correlation between ROS and cell viability observed in the present studies highly supported ROS generation was one of the major determinant factors in Cisplatin-induced cell death.

The reduction of UCP2-mediated antioxidant effect promoted the formation of ROS at high dose of Genipin [44], which contributed the Genipin-induced cell death in gastric cancer cell lines[33], hepatoma cells and PC3 human prostate cancer cell[26]. The potentiation effect of Genipin to the cytotoxicity of Cisplatin was likely via the reduction of UCP2-mediated antioxidative effect, enhancing the Cisplatin induced ROS generation [45] and triggering the subsequent ROS-mediated cell senescence.

\section{Interaction of leaked electron with Cisplatin in ROS generation}

As ATP production was impaired in mitochondria of cancer cells [17], mitochondrial dysfunction in cancer cells was then implicated [46]. However, our studies ${ }^{[35,36]}$ have observed extremely high mitochondrial activities occurring in cancers cells, in which significant amount of proton leak and electric current produced from cancer cells was observed [35,36]. The electric current production in cancer cells was much higher than that of the normal cells ${ }^{[35,36]}$ and the high electric current was associated with the proton leak from the overexpressed UCP2 in cancer cells [36]. Although significant amount of electron and proton flow to ETC was observed, the proton did not pass through the ATP synthase to power the production of ATP in cancer cells [41]. Instead, proton was leaked via the UCP2 to mitochondrial matrix [36]. The proton leak from UCP2 in cancer cell did not only provide high anti-oxidative effect to protect the cancer cells against chemotherapeutic agent causing drug resistance [15], it also recycled $\mathrm{NAD}^{+}$to maintain its availability for other biochemical process, e.g. glycolysis. Therefore, the mitochondrial function in cancer cells seemed to be altered but not totally dysfunction.

Using the technique of MFC, electric current production from cells could be measured [35,36], in which the electric current was contributed from the electron leak from ETC in mitochondria. Previous studies ${ }^{[35,36]}$ have also observed proton leak would promote the electric current production via maintaining the charge balance to enhance the further electron leak [35,36]. Therefore, DNP and RVT promoting the proton leak in cells increased the electric current production, while Genipin inhibiting UCP2 proton leak decreased the electric current [36].

Cisplatin was found to uncouple the ETC to promote electron and proton leak leading to the increase in electric current production in cancer cells. The presence of Cisplatin inhibited the uncoupling of DNP in promoting electric current, which indicated Cisplatin was a stronger uncoupler than DNP. When the concentration of Cisplatin dropped to low level after 24 hours, inhibition to DNP decreased and the cells were found to respond to DNP again in increasing the electric current production (Table 1). As the uncoupling mechanism of DNP was not associated with UCP2 [36], the inhibition of UCP2 by Genipin did not affect the uncoupling of DNP in increasing the electric current production [36]. Addition of Genipin to Cisplatin only slightly decreased the electric current production (Table 1), which suggested the uncoupling mechanism Cisplatin in HCT-116 colon cancer cells similar to that of DNP [47].

As Cisplatin reduced the activities of complexes I to IV in ETC, ${ }^{[43]}$ leading to the reduction of proton and electron flow and decreasing the electric current production. The reduction of electron flow explained why a stronger un-coupler Cisplatin generated a smaller electric current than that of DNP in control 
cells, and why RVT effect in promoting electric current production [36] via the inhibition of ATP synthase was reduced in the presence of Cisplatin [36]. As the ETC activities were already suppressed by Cisplatin, further inhibition of ETC activities might not produce significant effect.

Theoretically, decreased electron flow to ETC would reduce the ROS production in general [48], but Cisplatin effect in ROS generation was still strong to induce significant ROS production (Figure $2 b$ ). The interaction of Cisplatin with the leaked electron might be crucial in ROS generation, probably via the production of hydroxyl radical [49]. When the in situ staying time of leaked electron was decreased by detouring to MFC, the chance of it to interact with Cisplatin was alleviated leading to ROS reduction. It was consistent to the previous observation that inhibition of $\mathrm{NAD}(\mathrm{P}) \mathrm{H}$ oxidase with diphenyleniodonium chloride or apocynin decreasing the electron flow to ETC prevented the cisplatin-related ROS generation and subsequent cell death [50-52], while inhibition of Lactate dehydrogenase with oxamate and galloflavin increased it [39]. In order to enhance the recycling of $\mathrm{NAD}^{+}$, the inhibition of lactate dehydrogenase might promote the ETC activities to enhance the recycling of $\mathrm{NAD}^{+}$. The increased electron flow to ETC might explain the ROS elevation via the promotion of interaction probability between Cisplatin and leaked electron. Genipin's action in decreasing the UCP2- mediated proton leak ${ }^{[41]}$ or increasing the reverse electron transfer back to complex I [53] to promote the electron leak also allowed more opportunity for the interaction between the leaked electron and Cisplatin, resulting a significant increase in the Cisplatin-induced ROS.

\section{Temporal differences between the action of Genipin and Cisplatin}

Different co-treatment methods used for Genipin and Cisplatin was found to affect the therapeutic efficacy in treating HCT-116 colon cancer cells. Results indicated the temporal effect of Genipin was crucial in the potentiation of cytotoxicity of Cisplatin in HCT-116 colon cancer cells. In the present study, the low dose of Genipin treatment did not significantly affect the cell viability of HCT-116 colon cancer cells (Figure 2a) from 0 to 24 hours, but changes of MMP without affecting the cell viability were observed after the 24 hours treatment. During the initial treatment of Genipin, MMP was increased in a dose-dependent manner, which was likely contributed by the blocking of UCP2 causing the accumulation of proton in the inner membrane to increase the MMP [18]. However, after the cells were treated with Genipin for 24 hours, MMP was decreased dose-dependently. As the cell viability was not affected by the Genipin treatment, the decrease in MMP at 24 hours was likely contributed by the physiological changes induced by Genipin treatment. Previous studies reported that Genipin treatment would up-regulate the UCP2 mediated proton leak [25]. When the proton leak reduced the proton accumulation in the inner membrane, it contributed to the subsequent decrease in MMP. For Cisplatin treatment, the decrease in MMP was likely contributed by the induced cell death. As the induced cell death would take a relatively longer time, it explained the reason why the Cisplatin treated cells took 24 hours to decrease the MMP.

Similarly, temporal difference in ROS generation between Genipin and Cisplatin was observed. Although both Genipin and Cisplatin increased ROS almost dose-dependently, the time taken to accumulate significant amount of ROS in HCT-116 colon cancer cells seemed to be different between Genipin and Cisplatin. The effect of Genipin in ROS generation reached the maximal level after $10 \mathrm{~min}$ and remained the same at 24 hours, while that of Cisplatin took 24 hours, more obvious at $100 \mu \mathrm{M}$ Cisplatin ${ }^{[8]}$.

Although Cisplatin was effective in generating ROS, as revealed in the present study, the interaction with the leaked electron seemed to be crucial in ROS production. As UCP2 was found to be upregulated in cancer cells ${ }^{[18]}$, it promoted the antioxidant effect offered from the proton leak at UCP2 [19], which would likely prevent the leaked electron from interacting with Cisplatin. It might explain why Cisplatin has to take relatively long time to accumulate enough ROS and induced cell death that was reflected in their low MMP. When Genipin was used to block the UCP2-mediated proton leak [18], it increased the chance of Cisplatin interacting with leaked electrons, which promoted the Cisplatin-induced ROS formation ${ }^{[44,45]}$ and subsequent cell death.

Owing to the compensatory effect induced by Genipin treatment in up-regulating the UCP2 expression with time [54,55], it would increase the anti-oxidative UCP2-mediated proton leak decreased the Cisplatin-induced ROS and cell death. Therefore, shorter the Genipin pretreatment time seemed to be more effective than the longer one in potentiating the cytotoxicity of Cisplatin in HCT-116 colon cancer cells.

\section{Conclusions}

Cisplatin induced ROS generation negatively correlated with the cell viability of HCT-116 colon cancer cells, in which the interaction of Cisplatin with leaked electron in ETC seemed to be important. Detouring the leaked electron to MFC decreased the 
Cisplatin induced ROS. Cisplatin induced ROS formation was slow, which might be contributed by both lowering ETC activities by Cisplatin and high UCP2 antioxidant effect in cancer cells reducing the interaction time between Cisplatin and the leaked electron. Inhibition of the UCP2-mediated proton leak by Genipin promoted the ROS formation and potentiated the cytotoxicity of Cisplatin. However, the potentiation was reduced with time because of the compensatory effect induced by Genipin, shorter the Genipin pretreatment was better in potentiating the cytotoxicity of Cisplatin in HCT-116 colon cancer cells.

\section{Abbreviations}

Electron

Transport

Chain

(ETC),

2.4-dinitrophenol (DNP), Microbial Fuel cells (MFC), Mitochondrial membrane potential (MMP), Reactive oxygen species (ROS), Resveratrol (RVT).

\section{Acknowledgements}

Authors would like to thank the support from BNU-HKBU United International College Research Grant R201406 for this project

\section{Competing Interests}

The authors have declared that no competing interest exists.

\section{References}

1. Ly JD, Grubb DR, Lawen A. The mitochondrial membrane potential $(\Delta \psi \mathrm{m})$ in apoptosis; an update. Apoptosis 2003; 8: 115-128.

2. Weisthal S, Keinan N, Ben-Hail D, Arif T, Shoshan-Barmatz V. $\mathrm{Ca}(2+)$-mediated regulation of VDAC1 expression levels is associated with cell death induction. Biochim Biophys Acta. 2014; 1843 (10): 2270-81.

3. Tsuijimoto $Y$, Shimizu S. The voltage-dependent anion channel: an essential player in apoptosis. Biochimie 2002; 84 (2-3): 187-93.

4. Florea A, Busselberg D. Cisplatin as an Anti-Tumor Drug: Cellular Mechanisms of Activity, Drug Resistance and Induced Side Effects. Cancers 2011; 3:1351-1371.

5. Chen D, Milacic V, Frezza M, Dou QP. Metal complexes, their cellular targets and potential for cancer therapy. Curr. Pharm. 2009;15: 777-791

6. Pak JH, Choi WH, Lee HM, Joo WD, Kim JH, Kim YT, Kim YM, Nam JH. Peroxiredoxin 6 overexpression attenuates cisplatin-induced apoptosis in human ovarian cancer cells. Cancer Invest 2011; 29 (1):21-8.

7. Bułdak RJ, Polaniak R, Bułdak L, Zwirska-Korczala K, Skonieczna M, Monsiol A, Kukla M, Duława-Bułdak A, Birkner E. Short-term exposure to $50 \mathrm{~Hz}$ ELF-EMF alters the cisplatin-induced oxidative response in AT478 murine squamous cell carcinoma cells. Bioelectromagnetics 2012; 33 (8):641-651.

8. Shin YS, Song SJ; Kang SU; Hwang HS; Choi JW; Lee BH; Jung YS; Kim CH. A novel synthetic compound, 3-amino-3-(4-fluoro-phenyl)-1H-quinoline-2,4dione, inhibits isplatin-induced hearing loss by the suppression of reactive oxygen species: in vitro and in vivo study. Neuroscience 2013; 232:1-12.

9. Qu K, Lin T, Wang Z, Liu S, Chang H, Xu X, Meng F, Zhou L, Wei J, Tai M, Dong Y, Liu C. Reactive oxygen species generation is essential for cisplatin-induced accelerated senescence in hepatocellular carcinoma. Front Med 2014; 8 (2):227-35

10. Shirato A, Kikugawa T, Miura N, Tanji N, Takemori N, Higashiyama S, Yokoyama M. Cisplatin resistance by induction of aldo-keto reductase family 1 member C2 in human bladder cancer cells. Oncol Lett 2014; 7 (3): 674-678

11. Kim JS, Lee JH, Jeong WW, Choi DH, Cha HJ, Kim do H, Kwon JK, Park SE, Park JH, Cho HR, Lee SH, Park SK, Lee BJ, Min YJ, Park JW. Reactive oxygen species-dependent EndoG release mediates cisplatin-induced caspase-independent apoptosis in human head and neck squamous carcinoma cells. Int J Cancer 2008; 122 (3):672-80

12. Luanpitpong $S$, Nimmannit $U$, Chanvorachote $P$, Leonard SS, Pongrakhananon $\mathrm{V}$, Wang $\mathrm{L}$, Rojanasakul $\mathrm{Y}$. Hydroxyl radical mediates cisplatin-induced apoptosis in human hair follicle dermal papilla cells and keratinocytes through Bcl-2-dependent mechanism. Apoptosis 2011;16 (8):769-82.

13. $\mathrm{Hu}$ J, Friedman E. Depleting Mirk Kinase Increases Cisplatin Toxicity in Ovarian Cancer Cells. Genes Cancer 2010; 1 (8):803-811

14. Ma J, Yang J, Wang C, Zhang N, Dong Y, Wang C, Wang Y, Lin X. Emodin augments cisplatin cytotoxicity in platinum-resistant ovarian cancer cells via ROS-dependent MRP1 downregulation. Biomed Res Int 2014; 2014:107671.

15. Mailloux RJ, Adjeitey CN, Harper ME. Genipin-induced inhibition of uncoupling protein-2 sensitizes drug-resistant cancer cells to cytotoxic agents. PLoS One 2010; 5: e1328933.

16. Chen J, Lan T, Zhang W, Dong L, Kang N, Fu M, Liu B, Liu K, Zhang C, Hou J, Zhan Q. Dasatinib enhances cisplatin sensitivity in human esophageal squamous cell carcinoma (ESCC) cells via suppression of PI3K/AKT and Stat3 pathways. Arch Biochem Biophys 2015;575: 38-45.

17. Baffy G, Derdak Z, Robson SC. Mitochondrial recoupling: a novel therapeutic strategy for cancer? British Journal of Cancer 2011; 105: 469 - 474

18. Ayyasamy V, Owens KM, Desouki MM, Liang P, Bakin A, Thangaraj K, Buchsbaum DJ, LoBuglio AF, Singh KK. Cellular model of Warburg effect identifies tumor promoting function of UCP2 in breast cancer and its suppression by genipin. PLoS One. 2011; 6 (9): e24792.

19. Moukdar F, Robidoux J, Lyght O, Pi J, Daniel KW, Collins S. Reduced antioxidant capacity and diet-induced atherosclerosis in uncoupling protein-2-deficient mice. J Lipid Res 2009; 50 (1): 59-70.

20. Peng, $\mathrm{CH}$, Huang CN, Wang CJ. The Anti-Tumor Effect And Mechanisms Of Action Of Penta-Acetyl Geniposide. Curr. Cancer Drug Tar. 2005; 5: 299-305

21. Liu HT, He JL, Li WM, Yang Z, Wang YX, Yin J, Du YG, Yu C. Geniposide Inhibits Interleukin-6 And Interleukin-8 Production In Lipopolysaccharide-Induced Human Umbilical Vein Endothelial Cells By Blocking P38 And ERK1/2 Signaling Pathways. Inflamm. Res., 2010; 59(6): 451-461

22. Yang XF, Cai OR, He JP, Chu X, Wei MM, Feng XR, Xie XX et al. Geniposide, An Iridoid Glucoside Derived From Gardenia Jasminoides, Protects Against Lip Polysaccharide-Induced Acute Lung Injury In Mice. Planta Med., 2012; 78(6): 557-564.

23. Liu JH, Yin F, Zheng XX, Jing JJ, Hu YH. Geniposide, A Novel Agonist For GLP-1 Receptor, Prevents PC12 Cells From Oxidative Damage Via MAP Kinase Pathway. Neurochem. Int., 2007;51(6-7): 361-369

24. Liu JH, Yin F, Guo LX, Deng XH, Hu YH Neuroprotection of Geniposide Against Hydrogen Peroxide Induced PC12 Cells Injury: Involvement of PI3 Kinase Signal Pathway, Acta Pharmacol. Sin., 2009; 30:159-165.

25. Ma TT, Huang C, Zong GJ, Zha DJ, Meng XM, Li J, Tang WJ Hepatoprotective Effects Of Geniposide In A Rat Model Of Nonalcoholic Steatohepatitis. J. Pharm. Pharmacol., 2011; 63: 587-593.

26. Cao H, Feng Q, Xu W, Li X, Kang Z, Ren Y, Du L. Genipin induced apoptosis associated with activation of the c-Jun NH2-terminal kinase and p53 protein in HeLa cells. Biol Pharm Bull 2010; 33 (8): 1343-8

27. Guan L, Feng H, Gong D, Zhao X,,Cai L,Wu Q, Yuan B, Yang M, Zhao J, Zou $Y$. Genipin ameliorates age-related insulin resistance through inhibiting hepatic oxidative stress and mitochondrial dysfunction. Exp Gerontol 2013; 48 (12): 1387-94

28. Kojima K, Shimada T, Nagareda Y, Watanabe M, Ishizaki J, Sai Y, Miyamoto K, Aburada M Preventive Effect of Geniposide On Metabolic Disease Status In Spontaneously Obese Type 2 Diabetic Mice And Free Fatty Acid-Treated Hepg2 Cells. Biol. Pharm. Bull., 2011; 34(10): 1613-1618

29. Wu SY, Wang GF, Liu ZQ Rao JJ, Lü L, Xu W, Wu SG, Zhang JJ Effect Of Geniposide, A Hypoglycemic Glucoside, On Hepatic Regulating Enzymes In Diabetic Mice Induced By A High-Fat Diet And Streptozotocin. Acta Pharmacol. Sin., 2009; 30: 202-208.

30. Koo HJ, Song YS, Kim HJ, Lee YH, Hong SM, Kim SJ, Kim BC, Jin C, Lim CJ, Park EH. Antiinflammatory effects of genipin, an active principle of gardenia. Eur J Pharmacol 2004;495 (2-3): 201-8.

31. Zhang CY, Parton LE, Ye CP, Krauss S, Shen R, Lin CT, Porco Jr JA, Lowell BB. Genipin inhibits UCP2-mediated proton leak and acutely reverses obesityand high glucose-induced beta cell dysfunction in isolated pancreatic islets. Cell Metab 2006; 3: 417-427

32. Dando I, Fiorini C, Pozza ED, Padroni C, Costanzo C, Palmieri M, Donadelli M. UCP2 inhibition triggers ROS-dependent nuclear translocation of GAPDH and autophagic cell death in pancreatic adenocarcinoma cells. Biochim Biophys Acta 2013; 1833 (3): 672-9.

33. Ko H, Kim JM, Kim SJ, Shim SH, Ha CH, Chang HI. Induction of apoptosis by genipin inhibits cell proliferation in AGS human gastric cancer cells via Egr1/p21 signaling pathway. Bioorg Med Chem Lett 2015; Date of Electronic Publication: 2015 Aug 7

34. Yang X, Yao J, Luo Y, Han Y, Wang Z, Du L. P38 MAP kinase mediates apoptosis after genipin treatment in non-small-cell lung cancer H1299 cells via a mitochondrial apoptotic cascade. J Pharmacol Sci 2013; 121 (4): 272-81.

35. Poon $\mathrm{K}$, Chung TC, Xu C, Wang R. To investigate the correlation of proton leak and current produced from animal cells by microbial fuel cells. Am J Life Sci, 2014; 2(3): 176-181

36. Wang R, MoYung KC, Zhang MH, Poon K. UCP2- and non UCP2-mediated electric current in eukaryotic cells exhibits different properties. Environmental Science and pollution research 2015; (DOI: 10.1007/s11356-015-5155-6)

37. Jeong JJ, Park N, Kwon YJ, Ye DJ, Moon A, Chun YJ. Role of annexin A5 in cisplatin-induced toxicity in renal cells: molecular mechanism of apoptosis. J Biol Chem 2014; 289 (4):2469-81 
38. Lu Y, Cederbaum A The mode of cisplatin-induced cell death in CYP2E1-overexpressing HepG2 cells: modulation by ERK, ROS, glutathione, and thioredoxin. Free Radic Biol Med 2007; 43 (7):1061-75.

39. Manerba M, Di Ianni L, Fiume L, Roberti M, Recanatini M, Di Stefano G. Lactate dehydrogenase inhibitors sensitize lymphoma cells to cisplatin without enhancing the drug effects on immortalized normal lymphocytes. Eur J Pharm Sci 2015; 74: 95-102.

40. Wangpaichitr M, Sullivan EJ, Theodoropoulos G, Wu C, You M, Feun LG, Lampidis TJ, Kuo MT, Savaraj N. The relationship of thioredoxin-1 and cisplatin resistance: its impact on ROS and oxidative metabolism in lung cancer cells. Mol Cancer Ther 2012; 11 (3): 604-15

41. Baffy G. Uncoupling protein-2 and cancer. Mitochondrion 2010;10: 243-252.

42. Dalla PE, Fiorini C, Dando I, Menegazzi M, Sgarbossa A, Costanzo C, Palmieri $\mathrm{M}$, Donadelli M. Role of mitochondrial uncoupling protein 2 in cancer cell resistance to gemcitabine. Biochim Biophys Acta 2012; 1823 (10):1856-63

43. Kruidering M, Van de Water B, de Heer E, Mulder GJ, Nagelkerke JF. Cisplatin-induced nephrotoxicity in porcine proximal tubular cells: mitochondrial dysfunction by inhibition of complexes I to IV of the respiratory chain. J Pharmacol Exp Ther 1997; 280 (2): 638-49.

44. Zhou $\mathrm{H}$, Zhao J, Zhang X. Inhibition of uncoupling protein 2 by genipin reduces insulin-stimulated glucose uptake in 3T3-L1 adipocytes. Arch Biochem Biophys 2009; 486 (1): 88-93.

45. Pons DG, Nadal-Serrano M, Torrens-Mas M, Valle A, Oliver J, Roca P. UCP2 inhibition sensitizes breast cancer cells to therapeutic agents by increasing oxidative stress. Free Radic Biol Med 2015; 86: 67-77.

46. Pokorný J, Foletti A, Kobilková J, Vrba J. Mitochondrial Dysfunction and Disturbed Coherence: Gate to Cancer. Pharmaceuticals (Basel) 2015; 8 (4): 675-95.

47. Rieger D, McGowan LT, Cox SF, Pugh PA, Thompson JG. Effect of 2,4-dinitrophenol on the energy metabolism of cattle embryos produced by in vitro fertilization and culture. Reprod, Fertil, Develop, 2002; 14 (5-6): 339-43

48. Wang $Y$, Luo $X$, Pan $H$, Huang $W$, Wang $X$, Wen $H$, Shen $K$, Jin B. Pharmacological inhibition of NADPH oxidase protects against cisplatin induced nephrotoxicity in mice by two step mechanism. Food Chem Toxicol 2015 May 30.

49. Yoshida M, Fukuda A, Hara M, Terada A, Kitanaka Y, Owada S. Melatonin prevents the increase in hydroxyl radical-spin trap adduct formation caused by the addition of cisplatin in vitro. Life Sci 2003; 72 (15): 1773-80.

50. Kawai Y, Nakao T, Kunimura N, Kohda Y, Gemba M. Relationship of intracellular calcium and oxygen radicals to Cisplatin-related renal cell injury. J Pharmacol Sci 2006; 100 (1): 65-72.

51. Muscella A, Urso L, Calabriso N, Vetrugno C, Fanizzi FP, Storelli C, Marsigliante S. Functions of epidermal growth factor receptor in cisplatin response of thyroid cells. Biochem Pharmacol 2009; 77 (6): 979-92.

52. Kim HJ, Lee JH, Kim SJ, Oh GS, Moon HD, Kwon KB, Park C, Park BH, Lee HK, Chung SY, Park R, So HS. Roles of NADPH oxidases in cisplatin-induced reactive oxygen species generation and ototoxicity. J Neurosci 2010; 30 (11): $3933-46$

53. Turrens JF. Mitochondrial formation of reactive oxygen species. J Physiol.2003; 552: 335-344.

54. Ma S, Yang D, Li D, Tan Y, Tang B, Yang Y. Inhibition of uncoupling protein 2 with genipin exacerbates palmitate-induced hepatic steatosis. Lipids Health Dis 2012; 11: 154

55. Guan LL, Wang YF, Gong DZ, Yuan B, Wu Q, Zhu L, Jia XL, Liu MC, Zhao J, Zou Y. Establishment of the Chang liver cell line stably overexpressing human $\mathrm{UCP} 2$ gene and its effect on mitochondrial membrane potential and reactive oxygen species. Zhonghua Gan Zang Bing Za Zhi 2012; 20 (2):131-5 